\title{
NILAI WAKTU KENDARAAN PRIBADI DI KOTA BANDA ACEH
}

\author{
Noer Fadhly ${ }^{1}$, Roni Agusmaniza ${ }^{2}$ \\ 1) Mahasiswa Program Doktor Perencanaan Wilayah, Sekolah Pascasarna Universitas \\ Sumatera Utara, email: noer6637@gmail.com \\ ${ }^{2)}$ Program Studi Teknik Sipil, Fakultas Teknik, Universitas Syiah Kuala \\ Jl. Syech Abdul Rauf no.7 Darussalam Banda Aceh, email: rrnovrisa@gmail.com
}

\begin{abstract}
The value of travel time becomes an important part of the gains in the assessment of a transport project in terms of economic considerations. In this research, the calculation of the value of travel time for users of private vehicles in Banda Aceh. Purposes of calculating the value of travel time is to vote as a result of a wasted opportunity when used to produce something as a result of traveling purposes. Of the various methods that can be used to determine the value of travel time method selection transport modes (mode choice approach) with a stated preference survey data is either to be used in determining the value of time based on the use of public transport (labi-labi) as the second choice, but taken one more method is the method of income (income approach) as a comparison. As for the results in this study is the comparison of both methods is the method of choice of transport modes (mode choice approach) and method of income (income approach) to obtain the value of travel time for users of private vehicles in the city of Banda Aceh.
\end{abstract}

Keywords : Value Time, Mode of Transport, Income, Personal Vehicle, Transportation, Travel

\begin{abstract}
Abstrak: Nilai waktu perjalanan menjadi bagian yang penting dari keuntungan dalam pengkajian suatu proyek transportasi dalam hal pertimbangan ekonomis. Dalam penelitian ini dilakukan perhitungan nilai waktu perjalanan untuk pemakai kendaraan pribadi di Kota Banda Aceh. Tujuan menghitung nilai waktu perjalanan adalah dengan menilainya sebagai hasil dari kesempatan yang terbuang apabila digunakan untuk menghasilkan sesuatu akibat keperluan melakukan perjalanan. Dari bermacam-macam metode yang dapat digunakan untuk menentukan nilai waktu perjalanan metode pilihan moda angkutan (mode choice approach) dengan survey data dengan stated preference adalah baik untuk digunakan dalam menentukan nilai waktu yang mendasarkan pada penggunaan angkutan umum (labi-labi) sebagai pilihan kedua, namun diambil satu metode lagi yaitu metode pendapatan (income approach) sebagai perbandingan. Adapun hasil yang dicapai pada penelitian ini adalah perbandingan kedua metode yaitu metode pilihan moda angkutan (mode choice approach) dan metode pendapatan (income approach) untuk mendapatkan nilai waktu perjalanan untuk pengguna kendaraan pribadi di Kota Banda Aceh.
\end{abstract}

Kata kunci : Nilai Waktu, Moda Angkutan, Pendapatan, Kendaraan Pribadi, Transportasi, Perjalanan

Tingginya tingkat pertumbuhan kendaraan bermotor akibat dari peningkatan perekonomian masyarakat dan juga dari mudahnya regulasi untuk memperlohen kendaraan pribadi. Hal ini tercermin dari kenyataan semakin tingginya tingkat motorisasi penduduk dari tahun ke tahun.
Secara umum kendaraan bermotor terbagi menjadi dua jenis yaitu kendaraan umum dan kendaraan pribadi, dimana penggunaan kendaraan pribadi lebih banyak dari kendaraan umum, hal ini juga akibat kendaraan umum tidak dapat melayani ke semua rute perjalanan dan tidak terdapatnya 
terminal destination di Kota Banda Aceh selain itu juga disebabkan karena kendaraan pribadi biasanya memberikan tingkat pelayanan yang lebih baik dibandingkan dengan kendaraan umum baik yang dioperasikan oleh pemerintah maupun operator swasta. Meningkatnya jumlah kendaraan pribadi sehingga menyebabkan kemacetan dan bertambahnya Biaya Operasi Kendaraan (BOK) dan waktu perjalanan bertambah dimana nilai untuk waktu perjalanan yang berlaku bagi masing-masing individu berbeda.

Berdasarkan permasalahan di atas, dilakukan penelitian yang bertujuan untuk menghitung nilai waktu perjalanan pengguna kendaraan pribadi yang dimulai dari (Origin) depan Bank Syariah Mandiri, Jalan Diponegoro dan berakhir (Destination) pada Simpang Galon, Jalan T. Nyak Arif.

Tujuan menghitung nilai waktu perjalanan dengan menilainya sebagai hasil dari kesempatan yang terbuang apabila digunakan untuk menghasilkan sesuatu akibat keperluan melakukan perjalanan. Penaksiran nilai waktu ini berguna untuk mengetahui berapa biaya yang terbuang dikarenakan kemacetan lalu lintas yang menyebabkan bertambahnya waktu perjalanan.

Metode yang digunakan untuk mendapatkan nilai waktu adalah metode pilihan moda angkutan (mode choice approach) dan metode pendapatan (income approach).

\section{KAJIAN PUSTAKA}

Menurut Tamin (2008: 454), nilai waktu adalah sejumlah uang yang disediakan seseorang untuk dikeluarkan untuk menghemat satu unit waktu perjalanan. Nilai waktu biasanya sebanding dengan per kapita, merupakan perbandingan yang tetap dengan tingkat pendapatan.

Menurut LAPI - ITB (2000), waktu adalah biaya real dalam transport. Nilai waktu, atau lebih tepat, nilai penghematan waktu didefinisikan sebagai sejumlah nilai uang yang rela dibayarkan seseorang dalam rangka menghematkan satu unit waktu. Waktu yang dihemat/hilang diasumsikan memiliki opportunity cost bagi kegiatan produksi, sehingga nilai waktu bagi seorang dapat didekati dari tingkat pendapatan yang bersangkutan.

Winaryo (2002: 6) mengutip dari Horowitz (1980), menjelaskan bahwa faktorfaktor yang berpengaruh dalam menentukan nilai manfaat waktu perjalanan adalah:

1. Panjang perjalanan

2. Moda perjalanan

3. Periode waktu

4. Maksud perjalanan

5. Kondisi lingkungan

\section{Metode pendapatan (income approach)}

Nilai waktu perjalanan :

$(\lambda)=\underline{\text { PDRB } / \text { Orang }}$

Waktu Kerja Tahunan

Metode pilihan moda angkutan (mode choice approach)

$$
\begin{aligned}
& \mathrm{P}_{\mathrm{q}}=\mathrm{a}_{\mathrm{o}}+\mathrm{a}_{1}\left(\mathrm{C}_{\mathrm{p}}-\mathrm{C}_{\mathrm{q}}\right)+\mathrm{a}_{2}\left(\mathrm{~T}_{\mathrm{p}}-\mathrm{T}_{\mathrm{q}}\right) \\
& \lambda=\mathrm{a}_{2} / \mathrm{a}_{1}
\end{aligned}
$$


Dimana:

$\mathrm{P}_{\mathrm{q}} \quad=$ perbandingan pilihan moda $\mathrm{q}$, prosentase;

$\mathrm{C}, \mathrm{T}=$ biaya perjalanan $(\mathrm{C})$ dan waktu perjalanan $(\mathrm{T})$;

$\mathrm{P} \quad=$ kendaraan pribadi;

$\mathrm{q} \quad=$ kendaraan angkutan umum;

$\lambda=$ nilai waktu perjalanan;

$\mathrm{a}_{0,} \mathrm{a}_{1, \mathrm{a}_{2}}=$ koefisien.

\section{Logit model}

Pedekatan ini mencoba mendapatkan probabilitas, jika beberapa individu mempunyai pilihan antara rute $\mathrm{A}$ dan rute $\mathrm{B}$ untuk perjalan tertentu, bahwa rute A akan menjadi pilihan, dan bagaimana waktu dan biaya relatif mempengaruhi probabilitas.

Menurut LAPI - ITB (2000), pendekatan yang paling sering diterapkan pada teknik stated preference, untuk analisa data yang telah dikumpulkan adalah sebagai berikut:

1. Model pilihan diskrit (discrete choice models)

2. pendekatan regresi (regression approaches) - multiple regression

\section{Monotonic analysis of variance}

\section{Naive method}

Gaus (2010) mengutip Permain dan Swanson (1991), dalam stated preference techniques, A Guide to Practice untuk suatu penelitian yang menggunakan teknik stated prefence mengindentifikasikan penggunaan sampel yang dibutuhkan dalam jumlah yang besar, dan menyarankan dalam suatu studi penelitian transportasi jumlah sampelnya adalah 300 sampai dengan 400 sampel.

\section{METODE PENELITIAN}

\section{Metode Pengumpulan Data}

Data yang digunakan meliputi data primer yang diperoleh dari pengamatan langsung dilapangan, dengan cara melakukan wawancara dan pengisian kuesioner. Sedangkan data sekunder adalah data penunjang yang meliputi peta jaringan jalan, jumlah penduduk dan Produk Domestik Regional Bruto (PDRB) yang diperoleh dari instansi terkait.

\section{Variabel Penelitian}

Variabel yang digunakan adalah ini adalah Biaya Perjalanan (Cost) dan Waktu Perjalanan (Time). Format kuisioner yang akan disebarkan kepada responden, mengggunakan teknik point rating dengan sebelas point skala semantik dimana responden dapat mengekspresikan pilihannya.

\section{Metode Pengolahan Data}

Pengolahan data melihat probalitas pemilihan kendaraan angkutan umum pada waktu yang akan datang dalam hal perbedaan biaya, perbedaan waktu dan probabilitas dari pilihan moda, seperti yang diperoleh dari data kuesioner.

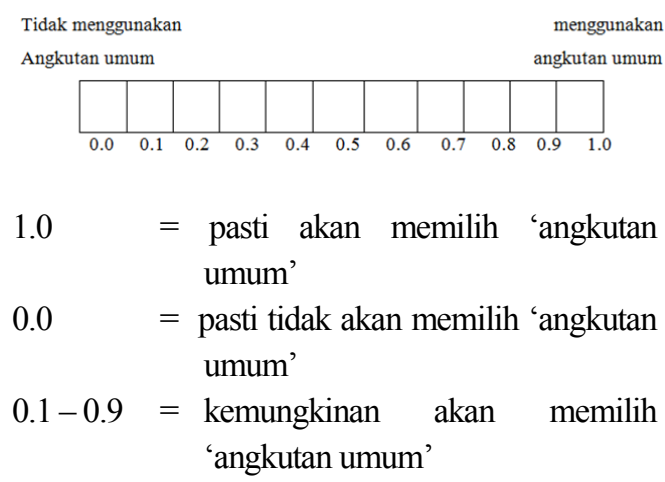


Nilai waktu dari perjalanan diperoleh dengan mengganti perbedaan biaya, perbedaan waktu dan probabilitas pilihan orang pada moda ke dalam persamaan model pilihan moda dengan teknik analisa stated preference. Nilai waktu perjalanan adalah perbandingan antara variabel perbedaan waktu dan variabel perbedaan biaya.

Hasil dari nilai survey dinyatakan dalam ketentuan dari tes statistic, Setelah ditentukan variabel bebas dan terikat $(\mathrm{Y}, \mathrm{X})$ dengan multi linear regresi, barulah diolah dengan metode pilihan moda angkutan (mode choice approach). Sedangkan metode pendapatan (income approach) langsung diolah dengan rumus yang telah dikemukakan pada tinjauan kepustakaan untuk mendapatkan hasil yang diperlukan dalam penelitian ini.

\section{HASIL PEMBAHASAN}

\section{Rekapitulasi Data}

Dari data yang dikumpulkan pada penelitian ini sejumlah 200 responden dan setelah dilakukan reduksi data baik tentang keabsahan dan konsistensi data maka diperoleh sejumlah 133 data valid dari responden yang dapat di kelompokkan menjadi:

1. Tujuan Perjalanan

\begin{tabular}{|l|l|l|}
\hline Tujuan Perjalanan & Orang & \%Orang \\
\hline \hline Bekerja & 93 & 69,9 \\
\hline Sekolah & 24 & 18 \\
\hline Belanja & 7 & 5,3 \\
\hline Lain-lain & 9 & 6,8 \\
\hline
\end{tabular}

2. Alasan Menggunakan Kendaraan Pribadi

\begin{tabular}{||l|l|l|}
\hline $\begin{array}{l}\text { Alasan Menggunakan } \\
\text { Kendaraan Pribadi }\end{array}$ & Orang & \%Orang \\
\hline \hline Waktu Tempuh & 54 & 40,6 \\
\hline Kemudahan & 45 & 33,8 \\
\hline $\begin{array}{l}\text { Keselamatan/Keamanan/ } \\
\text { Kenyamanan }\end{array}$ & 34 & 25,6 \\
\hline Biaya & 0 & 0 \\
\hline
\end{tabular}

3. Frekuensi Rata-Rata Menggunakan Kendaraan Pribadi dalam Satu Hari

\begin{tabular}{||l|l|l||}
\hline Frekuensi & Orang & \%Orang \\
\hline \hline 1-2 kali & 54 & 40,6 \\
\hline 2-4 kali & 56 & 42,1 \\
\hline $4-6$ kali & 16 & 12 \\
\hline$>6$ kali & 7 & 5,3 \\
\hline
\end{tabular}

4. Pengeluaran Perbulan

\begin{tabular}{|l|l|l||}
\hline $\begin{array}{l}\text { Jumlah Pengeluaran/Bulan } \\
\text { (Rp) }\end{array}$ & Orang & \%Orang \\
\hline \hline$<1.000 .000,-$ & 0 & 0 \\
\hline $1.000 .000-2.000 .000,-$ & 44 & 33,1 \\
\hline $2.000 .000-3.000 .000,-$ & 31 & 23,3 \\
\hline$>3.000 .000,-$ & 58 & 43,6 \\
\hline
\end{tabular}

5. Waktu Perjalanan

\begin{tabular}{||l|l|l||}
\hline Waktu Perjalanan & Orang & \%Orang \\
\hline \hline \pm 15 menit & 21 & 15,8 \\
\hline \pm 20 menit & 48 & 36 \\
\hline \pm 30 menit & 51 & 38,3 \\
\hline$>30$ menit & 13 & 9,9 \\
\hline
\end{tabular}

\section{Analisa korelasi tiga variable}

Koefisien korelasi yang dianggap baik adalah $\geq 0.6$ (Walpole, 1995) yang dikutip oleh (Winaryo, 2002), sedangkan koefisien 
korelasi yang diperoleh untuk dua variable.

a. semua variabel tidak terikat mempunyai korelasi yang cukup baik dengan variabel terikat dengan $\mathrm{r}<0.60$.

b. masing-masing variabel tidak terikat mempunyai korelasi yang baik dengan $r>0.6$ sehingga kedua variabel tidak terikat tersebut dapat digunakan untuk persamaan regresi linear berganda (multiple linear regression).

Dari penelitian ini diperoleh Nilai $\mathrm{R}^{2}$ yang dihasilkan adalah 7,5\%. ini menunjukkan bahwa model yang dihasilkan mempunyai kecocokan dan dapat digunakan.

Tabel 1. Hasil Uji Korelasi (r) Untuk Hubungan

Tiga Variabel
\begin{tabular}{|c|c|c|c|c|}
\hline \multicolumn{2}{|c|}{ Puebah } & $\mathrm{y}$ & $\mathrm{X} 1$ & $\mathrm{X} 2$ \\
\hline Rating & $\mathrm{Y} 1$ & 1.000 & - & - \\
\hline Biaya & $\mathrm{X} 1$ & 0.270 & 1.000 & - \\
\hline Waktu & $\mathrm{X} 2$ & 0.229 & 0.754 & 1.000 \\
\hline
\end{tabular}

Nilai Waktu Perjalanan Berdasarkan Pada Metode Pilihan Moda Angkutan (Mode Choice Approach)

Diperoleh persamaan regresi linear berganda: $\mathrm{Y}=0,431+0,000002933 \mathrm{X} 1+$ $0,073 \mathrm{X} 2$ Untuk menghitung nilai $\lambda$ (nilai waktu perjalanan) dengan data dari persamaan regresi linear berganda (multiple linear regression) dan dengan rumus $\lambda=$ a2/a1 maka nilai waktu perjalanan dapat diketahui yaitu Rp. 24.889,--

Nilai Waktu Perjalanan Berdasarkan Pada Metode Pendapatan (income Approach)

Dari data sekunder yang didapat adalah:
- Jumlah PDRB pada tahun 2010 adalah Rp 7.734.842.610.000,-

- Jumlah Penduduk Kota Banda Aceh pada tahun 2010 adalah 223.446 orang

- Jam kerja tahunan adalah 2.000 jam, berdasarkan pada:1 minggu mempunyai 40 jam kerja; dalam 1 tahun ada 50 minggu kerja efektif sehingga dengan menggunakan rumus Metode Pendapatan (income Approach) yaitu: Rp. 17.306,531/jam/orang

\section{KESIMPULAN DAN SARAN}

\section{Kesimpulan}

Hasil analisa didapatkan hasil adanya perbedaan yang cukup besar antara nilai waktu yang didapatkan dengan metode Pilihan Moda Angkutan (Mode Choice Approach) yaitu Rp. Rp. 24.889,- dengan hasil yang didapatkan menggunakan metode pendapatan (income Approach) yaitu Rp. 17.306,- hal ini menunjukkan bahwa metode pendapatan (income Approach) hanya dapat digunakan secara regional dan tidak dapat digunakan secara mendetail untuk suatu kasus tertentu atau mengarah kepada data yang digunakan hanya data sekunder yang tidak mengandung karakteristik secara khusus, namun merupakan gambaran umum dari suatu daerah.

Penerapan metode Pilihan Moda Angkutan (Mode Choice Approach) pada penentuan nilai waktu perjalanan adalah lebih baik sebab metode ini mengakomodasi pilihan seseorang pada moda perjalanan dan masih memperhatikan faktor lain yaitu waktu 
perjalanan dan biaya perjalanan, namun penerapan metode ini hanya dapat diterapkan pada kasus pulang balik (comutter).

\section{Saran}

Metode yang belum digunakan pada penelitian ini seperti dengan menggunakan metode-metode aset rumah, metode model distribusi lalu lintas, metode rasio pengalihan, metode pilihan kecepatan optimum dan metode batas tarif.

\section{DAFTAR PUSTAKA}

BPS, 2010, Hasil Sensus Penduduk 2010, Badan Pusat Statistik, Banda Aceh. BPS, 2010, Produk Domestik Regional Bruto 2010, Badan Pusat Statistik, Banda Aceh

Gaus, A., 2010, Kompetisi Pemilihan Moda Angkutan Umum Penumpang Antara Bus Dan Station Wagon, Fakultas Teknik Sipil Dan Perencanaan Institute Teknologi Sepuluh Nopember, Surabaya.
LAPI - ITB, Studi Perhitungan Nilai Waktu, PT. Jasa Marga, Bandung.

Silalahi, L. G., 2010, Analisa Pemilihan Moda Transportasi Bus Dangan Metode Stated Preference (Studi Kasus Medan-Sidikalang), Fakultas Teknik Univesitas Sumatera Utara, Medan.

Tamin,O.Z., 2008, Perencanaan dan Permodelan Transportasi, Penerbit ITB, Bandung.

Winaryo, D. E., 2002, Penaksiran Nilai Waktu Untuk Penumpang Kendaraan Pribadi Di Kota Semrang (Studi Kasus Jalan Majapahit-Jalan Simpang Lima), Program Pascasarjana Universitas Diponegoro, Semarang. 